\title{
Sistem Informasi untuk Monitoring Distribusi Obat di Indonesia
}

\author{
Yulisnaini Amelia ${ }^{1}$, Albarda $^{2}$, Elvi Trinovani ${ }^{3}$ \\ ${ }^{1,2,3}$ Sekolah Teknik Elektro dan Informatika, Institut Teknologi Bandung \\ e-mail:yulisnaini_amelia@yahoo.com, albar@stei.itb.ac.id,elvi_nova@yahoo.co.id
}

\begin{abstract}
Abstrak - Indonesia memiliki potensi penyakit yang beragam. Ketersediaan obat pada setiap tempat pendistribusian dan penjualan obat belum memadai. Pemerintah belum bisa menangani tidak meratanya penyebaran obat pada distributor obat. Saat ini, belum ada sebuah sistem informasi untuk memantau penyebaran dan pendistribusian obat secara nasional di indonesia. Sistem informasi tersebut dapat dibangun dengan menggunakan teknologi internet ataupun SMS gateway. Identifikasi dan analisis masalah yang dilakukan dengan menggunakan metode wawancara, observasi lapangan, dan studi literatur. Dari hasil identifikasi dan analisis masalah, diperoleh bagaimana keadaan penyebaran dan distribusi obat di Indonesia dan requirement apa saja yang dibutuhkan dalam merancang sistem informasi berskala nasional untuk memantau penyebaran dan pendistribusian obat di Indonesia. Hasil yang diperoleh berupa sistem interaksi mengenai data distribusi obat di Indonesia antara sarana pelayanan kesehatan dan sarana distribusi obat dengan Kementrian Kesehatan dan Dinas Kesehatan Provinsi, Dinas Kesehatan Kota/Kabupaten, serta masyarakat. Hasil yang diharapkan adalah agar rancangan ini dapat berguna dalam membangun sistem informasi yang sebenarnya dan berskala nasional untuk mengontrol dan mengatur penyebaran obat di Indonesia.
\end{abstract}

Keywords — pendistribusian, obat, SMS Gateway, monitoring.

\section{Pendahuluan}

Indonesia merupakan negara kepulauan yang sangat luas dan berpenduduk sangat padat. Selain jumlah penduduk yang banyak dan wilayah yang luas, Indonesia pun termasuk negara yang memiliki potensi penyakit yang beragam [4][5][7]. Penyakit merupakan kegagalan dari mekanisme adaptasi suatu organisme untuk bereaksi secara tepat terhadap rangsangan/tekanan sehingga timbul gangguan pada sistem atau fungsi dari tubuh [3]. Hal yang paling dibutuhkan untuk memberi pertolongan kepada penderita penyakit adalah ketersediaan obat yang memadai pada setiap tempat pendistribusian dan penjualan obat.

Seperti yang telah diamanatkan dalam UUD 1945 hasil amandemen, dalam Pasal $28 \mathrm{H}$ ayat (1) dikatakan bahwa setiap orang berhak hidup sejahtera lahir dan batin, bertempat tinggal, dan mendapatkan lingkungan hidup yang baik dan sehat serta berhak memperoleh pelayanan kesehatan. Di sini secara jelas diatur bahwa hidup secara sehat dan memperoleh pelayanan kesehatan merupakan hak setiap warga negara dan hal ini menjadi kewajiban bagi negara untuk merealisasikannya.

Masalah lain yang ada pada kondisi distribusi obat di Indonesia saat ini yaitu masih bebasnya peredaran obat-obatan di Indonesia [8]. Masih ada saja masyarakat yang berani membeli obat-obatan jenis keras tanpa saran dari tenaga kefarmasian [9]. Hal ini akan sangat berbahaya jika obat yang dibeli tidak sesuai dengan penyakit yang diderita oleh masyarakat tersebut.

Terdapat ribuan titik distribusi obat di Indonesia, mulai dari pabrik obat, sarana distribusi (Pedagang Besar Farmasi), dan juga sarana pelayanan (rumah sakit,puskesmas, dan apotek) [6]. Hal ini tentu menyebabkan pemerintah sulit mengontrol dan memantau bagaimana keberjalanan proses distribusi obat di seluruh Indonesia.

Penelitian ini merancang sebuah kebutuhan sistem informasi untuk monitoring data terkait distribusi obat di Indonesia. Sistem informasi yang dirancang dapat memberikan warning kepada Dinas Kesehatan pada aplikasi desktop terhadap pelanggaran-pelanggaran yang terjadi pada setiap proses bisnis yang dirancang.

\section{INISIASI SISTEM}

Tahap pertama dalam mendefinisikan solusi sistem informasi untuk monitoring distribusi obat adalah menentukan kebutuhan sistem dengan mencari permasalahan yang ada pada saat ini. Dalam mencari solusi sistem informasi, dilakukan dengan tahapan umum seperti inisiasi sistem, analisis sistem, dan desain sistem[1]. Pada tahap pertama ini, terdapat identifikasi masalah dan pemetaan masalah yang berhubungan dengan proses distribusi obat di Indonesia. Pemetaan masalah dilakukan pada empat stakeholder, yaitu Pemerintah, sarana distribusi (PBF), sarana pelayanan, dan masyarakat.

\section{A. Obat-Obatan yang Didistribusikan}

Obat-obatan yang didistribusikan di Indonesia, terdiri dari berbagai macam jenis, kategori, dan fungsi. Tabel 1 berikut menunjukkan kategori obat berdasarkan tingkat kebebasan dalam memperolehnya.

TABEL1

KATEGORI OBAT BERDASARKAN TINGKAT KEBEBASANNYA

\begin{tabular}{|l|l|l|}
\hline No. & Kategori & Penjelasan \\
\hline 1. & $\begin{array}{l}\text { Obat Bebas (terdapat } \\
\text { lingkaran hijau dengan } \\
\text { garis tepi berwarna hitam } \\
\text { pada kemasan obat) }\end{array}$ & $\begin{array}{l}\text { Obat yang dijual secara bebas di } \\
\text { pasaran dan dapat dibeli tanpa } \\
\text { resep dokter. }\end{array}$ \\
\hline 2. & $\begin{array}{l}\text { Obat Bebas Terbatas } \\
\text { (terdapat lingkaran biru } \\
\text { dengan garis tepi } \\
\text { berwarna hitam pada } \\
\text { kemasan obat) }\end{array}$ & $\begin{array}{l}\text { Obat yang masih termasuk obat } \\
\text { keras, tetapi masih dapat dijual } \\
\text { atau dibeli bebas tanpa resep } \\
\text { dokter dan disertai dengan tanda } \\
\text { peringatan. }\end{array}$ \\
\hline
\end{tabular}




\begin{tabular}{|l|l|l|}
\hline 3. & $\begin{array}{l}\text { Obat Keras dan } \\
\text { Psikotropika (terdapat } \\
\text { huruf K dalam } \\
\text { lingkaran merah dengan } \\
\text { garis tepi berwarna } \\
\text { hitam pada kemasan } \\
\text { obat) }\end{array}$ & $\begin{array}{l}\text { Obat yang hanya dapat dibeli di } \\
\text { apotek dengan resep dokter. }\end{array}$ \\
\hline 4. & Obat Narkotika & $\begin{array}{l}\text { Obat yang dapat menyebabkan } \\
\text { penurunan atau perubahan } \\
\text { kesadaran, serta mengurangi } \\
\text { sampai menghilangkan rasa } \\
\text { nyeri dan menimbulkan } \\
\text { ketergantungan. }\end{array}$ \\
\hline
\end{tabular}

Selain berdasarkan tingkat kebebasan, juga terdapat pembagian obat ke dalam kategori obat generik dan obat paten. Obat generik lebih murah dari obat paten karena biaya pembuatannya disubsidi oleh pemerintah. Dalam perancangan sistem informasi monitoring distribusi obat ini, diambil sampel dalam jenis obat generik karena dalam praktik sehari-hari, banyak ditemukan pelanggaran dalam pendistribusian dan penggunaan obat generik.

\section{B. Masalah pada Pemerintah (Kementrian Kesehatan, Dinas Kesehatan Provinsi, dan Dinas Kesehatan Kabupaten/ Kota)}

Direktorat Jenderal Bina Kefarmasian dan Alat Kesehatan pada Kementrian Kesehatan merupakan bagian yang mengurus distribusi obat. Dinas Kesehatan Provinsi dan Dinas Kesehatan Kabupaten/Kota memiliki peran yang berbeda dalam proses distribusi obat. Dinas Kesehatan Provinsi menerima pelaporan distribusi dan ketersediaan obat yang berasal dari sarana distribusi, yaitu Pedagang Besar Farmasi. Sedangkan Dinas Kesehatan Kabupaten/Kota, menerima pelaporan distribusi dan ketersediaan obat yang berasal dari sarana pelayanan, seperti Apotek, Puskesmas dan Rumah Sakit.Beberapa masalah yang terjadi pada pemerintah terkait dengan proses distribusi obat di Indonesiaadalah sebagai berikut:

- Kementrian Kesehatan belum memiliki sebuah sistem informasi yang berisi database mengenai pendistribusian obat berskala nasional.

- Belum ada sistem informasi yang dapat memperlihatkan data pendistribusian obat secara real time.

- Data yang diterima dan ditampilkan pada sistem saat ini tidak detail.

- Dinas Kesehatan Provinsi Jawa Barat menerima laporan mengenai pendistribusian obat dalam bentuk tertulis (hardcopy) dari Dinas Kesehatan Kabupaten/Kota.

\section{Masalah pada Sarana Distribusi (PBF)}

Beberapa permasalahan yang ada pada sarana distribusi atau PBF pada proses distribusi obat adalah sebagai berikut:

- Masih ada PBF yang tidak memenuhi persyaratan mutu dalam melakukan pengadaan, penyimpanan, dan menyalurkan obat seperti yang sudah ditetapkan pada Peraturan Kementrian Kesehatan No.1148 Tahun 2011 pasal 13.
- Masih ada PBF yang tidak memiliki apoteker.

- Beberapa PBF tidak melaksanakan pengadaan, penyimpanan, dan penyaluran obat sesuai dengan CDOB (Cara Distribusi Obat yang Baik) yang ditetapkan oleh Menteri Kesehatan.

- Masih ada PBF yang tidak melaporkan kegiatannya kepada Kementrian Kesehatan dan Dinas Kesehatan Provinsi selama 3 bulan sekali.

- Tidak ada batasan jumlah order yang dapat dilakukan oleh sebuah PBF kepada pabrik obat ataupun PBF lainnya.

D. Masalah pada Sarana Pelayanan (Rumah Sakit, Puskesmas, dan Apotek)

Masalah yang ditemukan pada sarana pelayanan dalam mendistribusikan obat adalah:

- Masih banyak sarana pelayanan kesehatan pemerintah yang tidak menyediakan obat generik untuk pasiennya. Hal ini bertentangan dengan Peraturan Menteri Kesehatan RI No. 068 tahun 2010 pasal 2.

- Masih banyak sarana pelayanan yang tidak melaksanakan semua kegiatan tersebut sesuai dengan rencana, dilihat dari tidak meratanya persebaran obat pada sarana pelayanan.

- Masih ada pihak yang menjual obat generik jenis keras tanpa menggunakan resep dari dokter.

- Masih ditemukannya pihak nakal yang menjual obat generik melebihi harga jual tertinggi yang telah ditentukan.

- Banyaknya dokter yang masih memberikan resep obat paten, disaat terdapat obat generiknya.

\section{E. Masalah pada Masyarakat}

Beberapa masalah yang terjadi pada masyarakat sebagai konsumen terkait penyebaran obat generik adalah sebagai berikut:

- Sosialisasi mengenai obat generik yang masih kurang, sehingga belum semua masyarakat mengetahui bagaimana kualitas obat generik yang sebenarnya sama saja dengan obat paten.

- Masih banyak masyarakat yang berani membeli obat generik dengan jenis keras tanpa menggunakan resep.

- Masyarakat yang tidak mengetahui berapa harga eceran obat generik yang seharusnya, sehingga mudah dikelabui oleh sarana pelayanan kesehatan yang nakal dengan menjual obat generik melebihi harga yang sudah ditetapkan.

\section{ANALISIS SISTEM}

Pada tahap analisis sistem ini, dilakukan pemahaman lebih lanjut terhadap masalah yang ada serta menghasilkan requirement dari solusi yang dirancang. 


\section{A. Analisis Masalah}

Dari masalah yang telah ditemukan pada tahap sebelumnya, dilakukan analisis untuk menemukan domain-domain masalah apa saja yang berkaitan dengan masalah pada monitoring distribusi obat yang ada saat ini. Domain-domain tersebut adalah perencanaan, pengawasan, sosialisasi, dan pelaporan. Domain permasalahan serta akar dari masalah ditunjukkan pada Gambar 1.

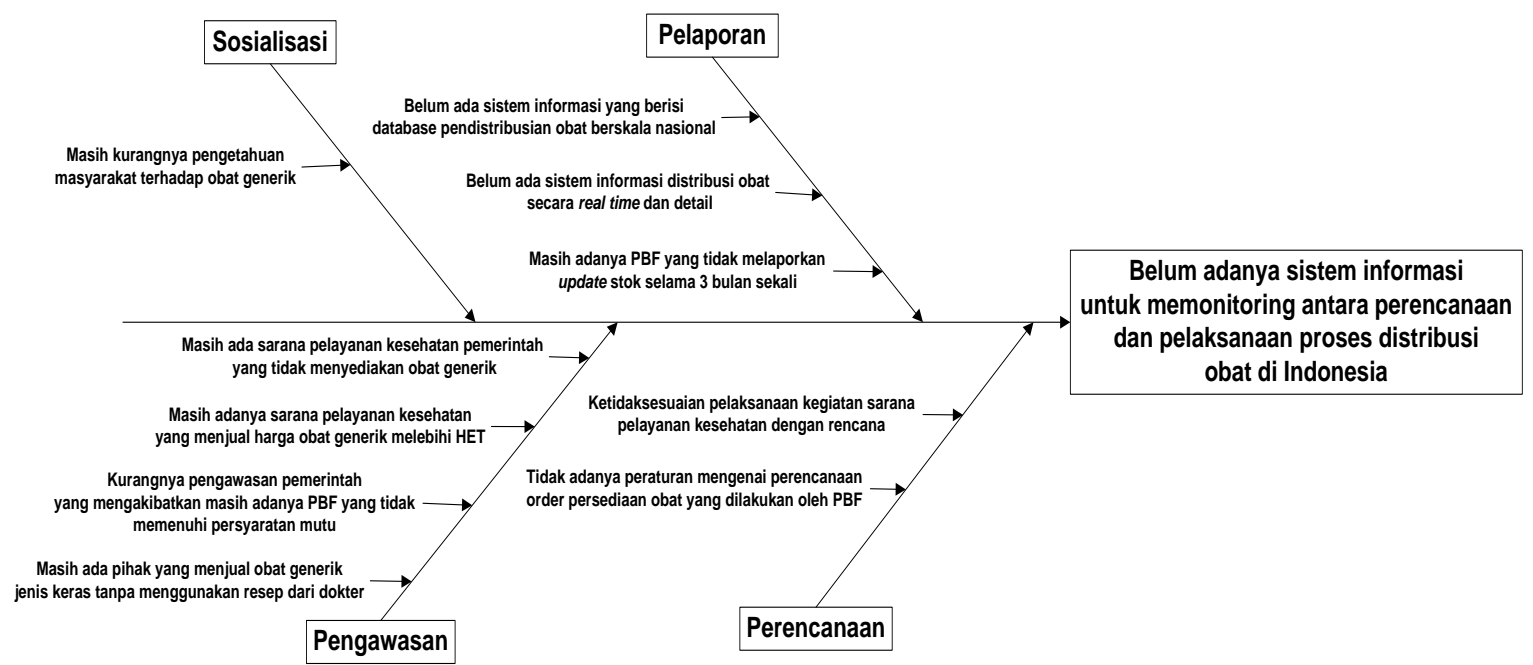

Gambar 9: Diagram Ishikawa Masalah Pendistribusian Obat di Indonesia

Analisis permasalahan dari gambar tersebut menunjukkan bahwa dibutuhkan sistem informasi untuk memonitoring antara perencanaan dan pelaksanaan proses distribusi obat di Indonesia yang belum ada saat ini.

\section{B. Identifikasi Requirement Sistem}

Sistem informasi untuk monitoring distribusi obat berskala nasional ini, dapat dilakukan dengan merancang sebuah sistem pelaporan data dengan menggunakan SMS dan dipantau oleh pemerintah melalui aplikasi desktop. Kebutuhan sistem informasi monitoring distribusi obat berskala nasional ini adalah sebagai berikut:

- Sistem berisi database nomor telepon pemangku kepentingan dari sarana distribusi, sarana pelayanan kesehatan, serta pemerintah yang bersangkutan.

- Sistem memiliki database nama PBF di masing-masing provinsi di Indonesia, nama sarana pelayanan kesehatan di masing-masing kabupaten/kota di Indonesia, stok obat pada masing-masing sarana distribusi dan pelayanan kesehatan, HET dari obat generik, obat generik jenis keras yang memerlukan resep, serta informasi lainnya yang dibutuhkan pada sistem.

- Sistem dapat menerima informasi dari pengguna dengan menggunakan SMS dengan format yang telah ditentukan.

- Sistem dapat memberikan balasan mengenai format $S M S$ yang benar kepada pengirim SMS apabila $S M S$ yang dikirimkan formatnya tidak benar.

- Sistem dapat menampilkan notifikasi apabila terdapat ketidaksesuaian rencana dengan pelaksanaan kegiatan distribusi obat di sarana pelayanan.

- Sistem dapat memperlihatkan jumlah obat yang dipesan oleh masing-masing PBF dan menampilkan notifikasi apabila jumlah tersebut melebihi batas yang ditentukan.
- Sistem dapat menampilkan informasi kegiatan distribusi obat se-real time mungkin.

- Sistem dapat menampilkan notifikasi apabila terdapat sarana pelayanan kesehatan yang menjual obat generik melebihi HET yang telah ditentukan.

- Masyarakat dapat mengakses data HET dan harga eceran obat generik pada setiap sarana pelayanan.

- Sistem dapat menampilkan notifikasi jika terdapat ketidaksesuaian antara jumlah resep obat generik yang seharusnya dengan jumlah resep yang dikeluarkan oleh dokter pada sarana pelayanan.

- Server pusat sistem berada pada pemerintah pusat, yaitu Kementrian Kesehatan.

\section{DESAIN SISTEM}

Pada tahap desain sistem ini, terdapat dua bagian utama yaitu mengidentifikasi alternatif solusi dan menentukan pilihan terbaik serta mendesain solusi yang dipilih.

\section{A. Identifikasi Alternatif Solusi dan Alternatif Teknologi}

Terdapat dua buah alternatif solusi untuk merancang sistem informasi monitoring distribusi obat, yaitu:

- Pembuatan sistem informasi monitoring distribusi obat. Maksud dari monitoring disini adalah memantau dan mengawasi apakah pelaksanaan kegiatan distribusi obat sesuai dengan perencanaan yang telah dibuat atau tidak.

- Pembuatan sistem informasi pendataan stok obat dengan memperlihatkan stok awal obat, jumlah obat yang didistribusikan, serta stok akhir obat pada masingmasing pemangku kepentingan yang berperan pada proses distribusi obat, yaitu pemerintah, sarana distribusi, serta sarana pelayanan. 
Dari kedua alternatif solusi tersebut, dilakukan perbandingan menggunakan balance scorecard yang ditunjukkan pada Tabel 2.

TABEL2

BALANCE SCORECARD ALTERNATIF SOLUSI

\begin{tabular}{|c|c|c|}
\hline Kategori & Sistem Monitoring & Sistem Pendataan Stok \\
\hline 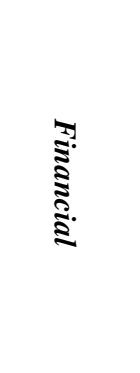 & $\begin{array}{l}\text { Membutuhkan dana } \\
\text { yang tidak terlalu besar } \\
\text { karena server berada } \\
\text { pada pemerintah pusat, } \\
\text { yaitu Kementrian } \\
\text { Kesehatan sedangkan } \\
\text { pemangku kepentingan } \\
\text { lainnya dapat } \\
\text { menggunakan teknologi } \\
\text { yang murah. }\end{array}$ & $\begin{array}{l}\text { Sistem ini membutuhkan } \\
\text { dana yang cukup besar } \\
\text { jika sistem yang berada } \\
\text { pada setiap pemangku } \\
\text { kepentingan berupa } \\
\text { teknologi yang } \\
\text { konvensional. }\end{array}$ \\
\hline 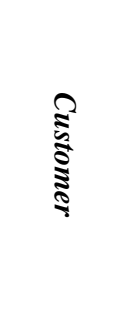 & $\begin{array}{l}\text { Sarana distribusi dan } \\
\text { sarana pelayanan } \\
\text { kesehatan sebagai } \\
\text { pengguna dari sistem ini } \\
\text { dilibatkan secara } \\
\text { langsung dalam } \\
\text { memasukkan data yang } \\
\text { dimonitor oleh pusat. }\end{array}$ & $\begin{array}{l}\text { Sarana distribusi dan } \\
\text { sarana pelayanan } \\
\text { dilibatkan langsung dalam } \\
\text { memasukkan data stok } \\
\text { obat pada masing-masing } \\
\text { sistem yang dimiliki. }\end{array}$ \\
\hline 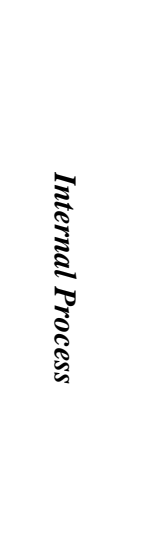 & $\begin{array}{l}\text { Sistem terpusat pada } \\
\text { pemerintah pusat yaitu } \\
\text { Kementrian Kesehatan } \\
\text { dan dibantu dengan } \\
\text { kerja sama Dinas } \\
\text { Kesehatan } \\
\text { Provinsi/Kabupaten/Kot } \\
\text { a melalui sebuah } \\
\text { aplikasi. Melalui sistem } \\
\text { ini, pemerintah dapat } \\
\text { memonitor antara } \\
\text { perencanaan dengan } \\
\text { pelaksanaan distribusi } \\
\text { obat pada setiap } \\
\text { pemangku kepentingan. }\end{array}$ & $\begin{array}{l}\text { Sistem tersebar dan } \\
\text { terdapat pada masing- } \\
\text { masing pemangku } \\
\text { kepentingan, namun tetap } \\
\text { berpusat pada pemerintah } \\
\text { pusat. Pada sistem ini } \\
\text { pemerintah pusat dapat } \\
\text { melihat stok obat pada } \\
\text { masing-masing pemangku } \\
\text { kepentingan. }\end{array}$ \\
\hline 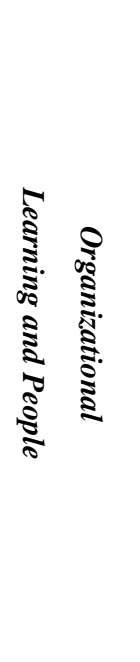 & $\begin{array}{l}\text { Sistem ini memberikan } \\
\text { tampilan mengenai } \\
\text { perencanaan dan } \\
\text { pelaksanaan distribusi } \\
\text { obat (dalam bentuk } \\
\text { jumlah obat yang } \\
\text { didistribusikan). Jika } \\
\text { ada ketidaksesuaian } \\
\text { antara rencana dengan } \\
\text { pelaksanaan, dapat } \\
\text { terlihat oleh pemerintah } \\
\text { sehingga dapat } \\
\text { ditindaklanjuti.Terdapat } \\
\text { notifikasi apabila terjadi } \\
\text { ketidaksesuaian antara } \\
\text { perencanaan dengan } \\
\text { pelaksanaan distribusi } \\
\text { obat. }\end{array}$ & $\begin{array}{l}\text { Sistem ini menampilkan } \\
\text { data stok obat pada setiap } \\
\text { pemangku kepentingan. } \\
\text { Stok yang ditampilkan } \\
\text { berupa stok awal obat, } \\
\text { jumlah obat yang } \\
\text { didistribusikan, serta stok } \\
\text { akhir obat. Pemerintah } \\
\text { pusat hanya dapat melihat } \\
\text { data stok tersebut dan } \\
\text { menganalisis lebih lanjut } \\
\text { data tersebut secara } \\
\text { manual tanpa ditampilkan } \\
\text { pada sistem.Tidak } \\
\text { terdapat notifikasi apapun } \\
\text { karena sistem hanya } \\
\text { menampilkan data stok } \\
\text { obat. }\end{array}$ \\
\hline
\end{tabular}

Dari tabel tersebut, dapat terlihat bahwa sistem informasi monitoring lebih banyak kelebihannya dibandingkan dengan sistem pendataan stok obat. Maka, dipilihlah sistem informasi monitoring distribusi obat untuk mengatasi permasalahan dalam kegiatan distribusi obat di Indonesia.

Selanjutnya, juga diperlukan alternatif teknologi yang sesuai dengan kondisi calon pengguna sistem ini. Teknologi yang dapat digunakan adalah SMS Gateway [2][10] dan juga Web-based . Perbandingan kedua teknologi tersebut dapat dilihat pada Tabel 3 berikut.

TABEL 3

PERBANDINGAN TEKNOLOGI

\begin{tabular}{|l|l|l|}
\hline Perbandingan & SMS Gateway & Web-based \\
\hline & $\begin{array}{l}\text { Lebih mudah untuk } \\
\text { diaplikasikan pada } \\
\text { setiap pemangku } \\
\text { kepentingan karena } \\
\text { saat ini jarang sekali } \\
\text { orang yang tidak } \\
\text { memiliki handphone } \\
\text { dan dapat dijangkau di } \\
\text { seluruh daerah } \\
\text { Indonesia. }\end{array}$ & $\begin{array}{l}\text { Proses } \text { update } \\
\text { informasi dan } \\
\text { pengiriman informasi } \\
\text { dapat dilakukan } \\
\text { dengan cepat, } \\
\text { serta lebih mudah dan } \\
\text { efisien dalam } \\
\text { memasukkan data. }\end{array}$ \\
& $\begin{array}{l}\text { Proses pengiriman } \\
\text { informasi dan update } \\
\text { informasi } \\
\text { membutuhkan waktu } \\
\text { yang lebih lama, tidak } \\
\text { efisien dalam } \\
\text { memasukkan data } \\
\text { dalam jumlah yang } \\
\text { banyak. }\end{array}$ & $\begin{array}{l}\text { Tidak semua daerah di } \\
\text { Indonesia memiliki } \\
\text { koneksi internet, } \\
\text { sehingga tidak dapat } \\
\text { dijangkau oleh seluruh } \\
\text { daerah di Indonesia, } \\
\text { selain itu masih ada } \\
\text { pemangku kepentingan } \\
\text { yang tidak mengerti } \\
\text { cara menggunakan } \\
\text { internet. }\end{array}$ \\
\hline &
\end{tabular}

Sistem informasi monitoring distribusi obat ini harus dapat menjangkau seluruh wilayah di Indonesia. Walaupun teknologi Web-based lebih banyak memiliki kelebihan dibandingkan dengan teknologi SMS Gateway, untuk pengiriman data, teknologi SMS Gateway lah yang paling tepat dan sesuai untuk dipilih dalam pembuatan solusi sistem informasi monitoring ini.

\section{B. Desain Solusi}

Pada solusi yang dirancang, yaitu sistem informasi monitoring distribusi obat, terdapat empat buah proses bisnis sesuai dengan tujuan dan fungsinya masing-masing. Masingmasing proses bisnis tersebut adalah pelaporan data stok obat dari PBF, pelaporan data stok obat dari sarana pelayanan, pelaporan harga obat generik pada sarana pelayanan, dan pelaporan jumlah resep pada sarana pelayanan. Gambar 2 berikut merupakan diagram hubungan antara keenam stakeholder dalam sistem informasi monitoring distribusi obat dengan menggunakan SMS Gateway. 


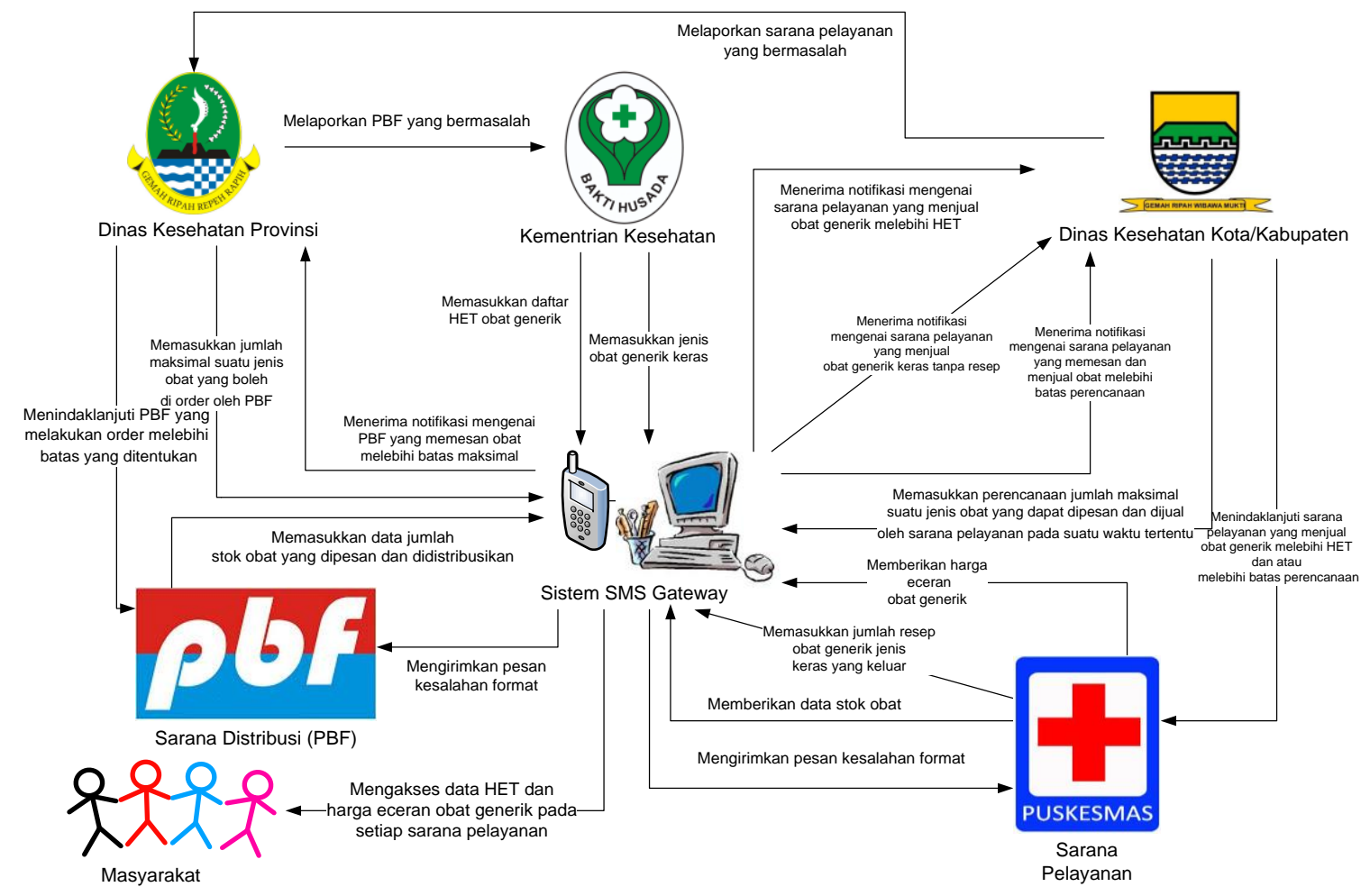

Gambar 10: Diagram Hubungan Sistem dengan Keenam Stakeholder

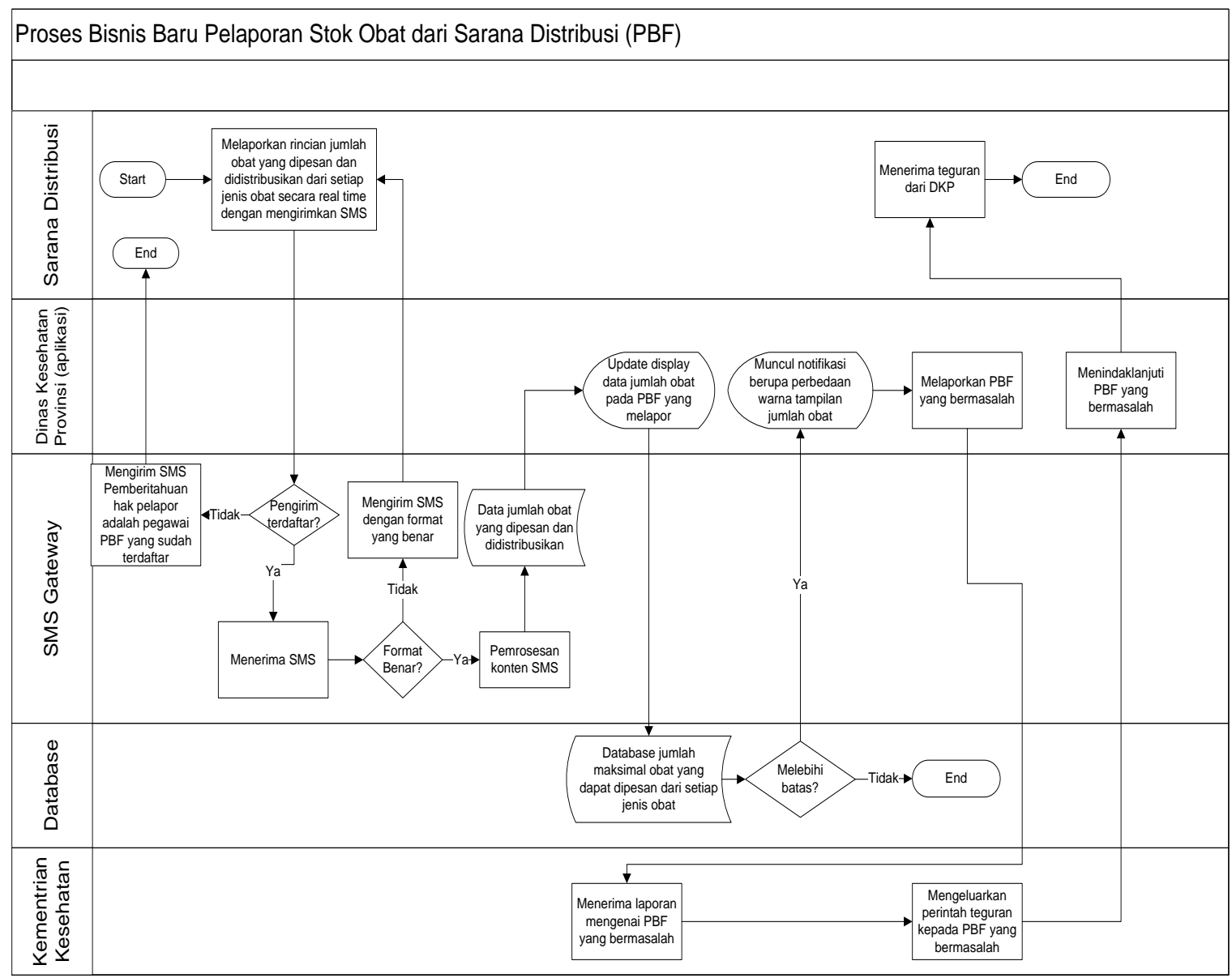

Gambar 11: Proses Bisnis Pelaporan Stok Obat PBF 
Gambar 3 di atas menunjukkan rancangan proses bisnis dalam pelaporan stok obat dari PBF kepada Dinas Kesehatan Provinsi.

Pelaporan stok obat dari PBF dan sarana pelayanan memiliki tahapan yang sama, hanya berbeda database yang dituju serta penanggung jawab dari pelaporan tersebut. Dinas Kesehatan Provinsi bertanggung jawab untuk pelaporan dari PBF, sedangkan Dinas Kesehatan Kota/Kabupaten bertanggung jawab untuk pelaporan dari sarana pelayanan.
Gambar 4 berikut menunjukkan perancangan proses bisnis pelaporan stok obat dari sarana pelayanan.

Dalam proses bisnis pelaporan harga obat generik, masyarakat juga dapat turut serta dalam melihat data yang dikirimkan oleh sarana pelayanan karena sebagai konsumen, masyarakat dapat menjadi pengawas memastikan kebenaran data yang dikirimkan oleh sarana pelayanan. Perancangan proses bisnis pelaporan harga obat generik yang dijual pada sarana pelayanan ditunjukkan pada Gambar 5 berikut.

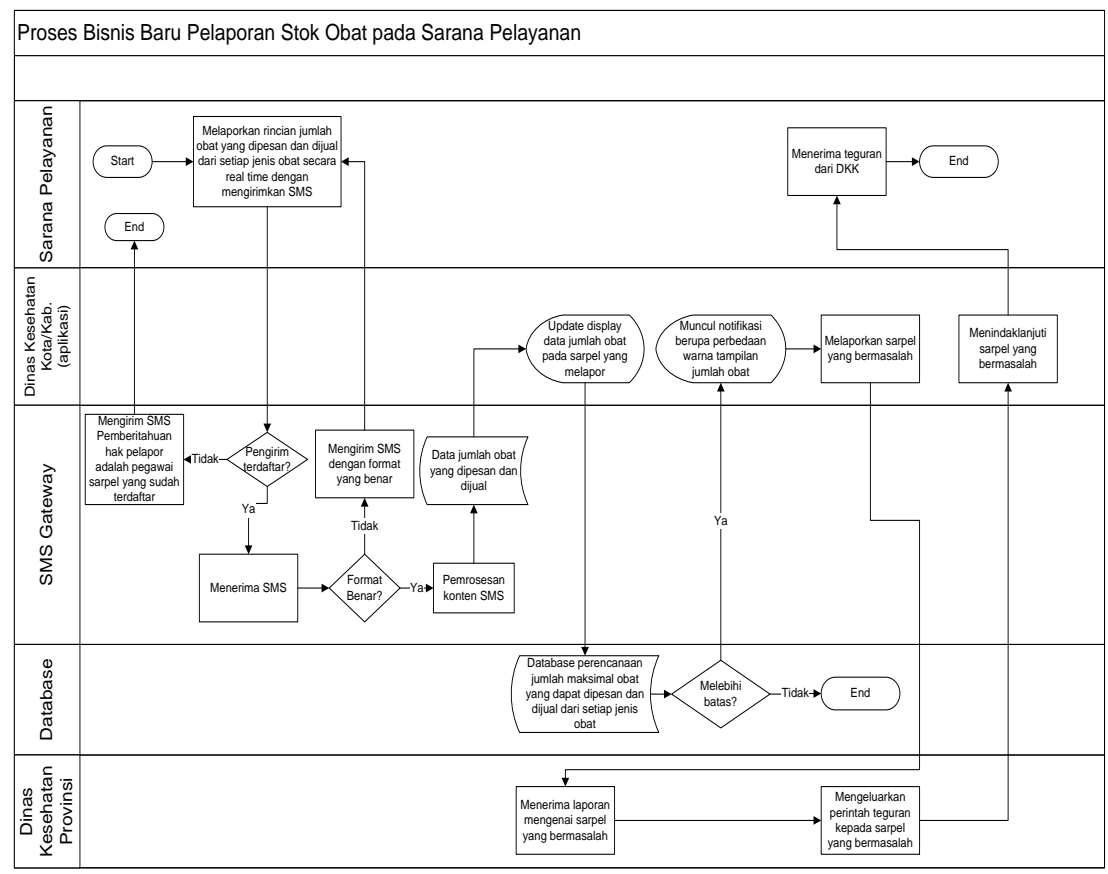

Gambar 12: Proses Bisnis Pelaporan Stok Obat Sarana Pelayanan

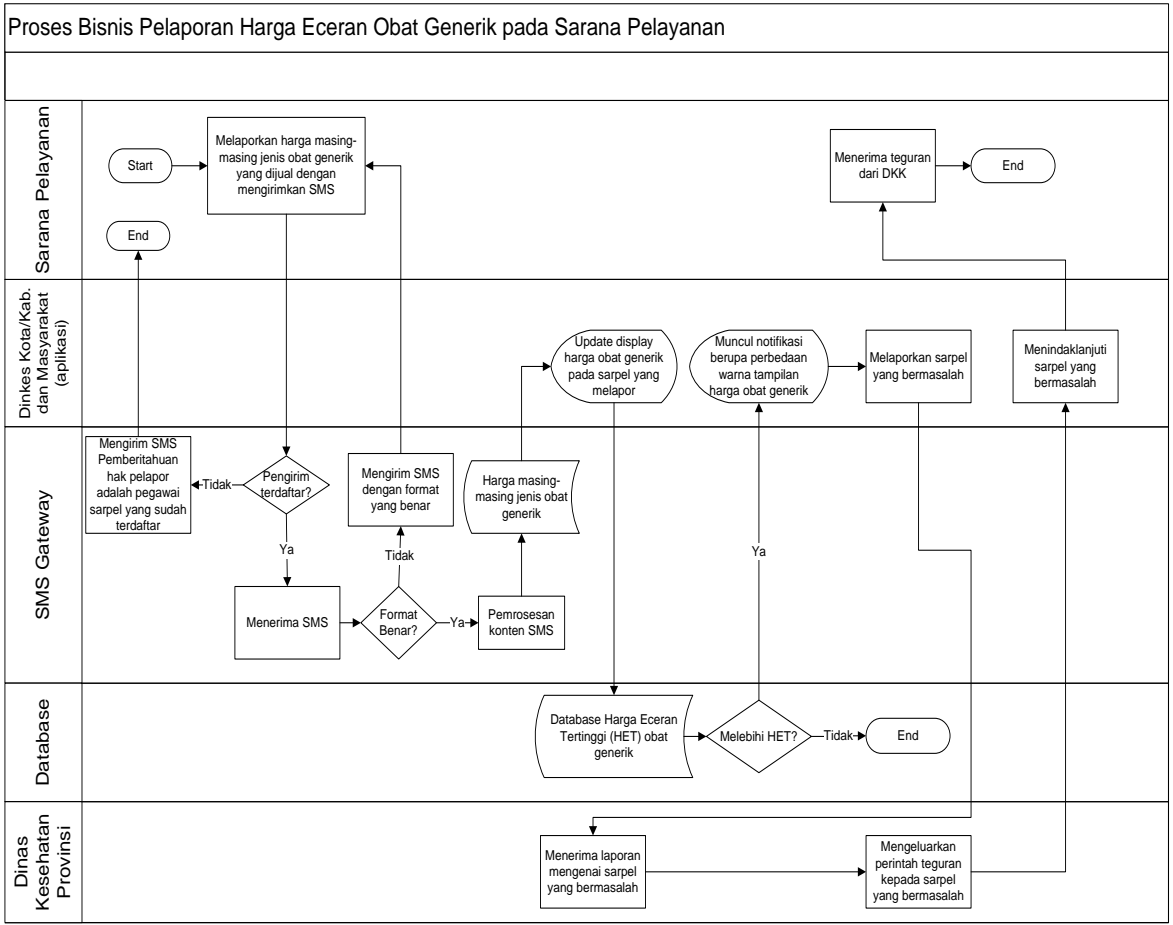

Gambar 13: Proses Bisnis Pelaporan Harga Obat Generik Sarana Pelayanan

Proses bisnis terakhir yang dirancang adalah dalam pelaporan jumlah resep yang keluar untuk obat generik keras pada sarana pelayanan. Gambar 6 berikut menunjukkan proses bisnis pelaporan jumlah resep yang keluar untuk obat generik keras dari sarana pelayanan. 
Jurnal Edukasi dan Penelitian Informatika (JEPIN) Vol. 1, No. 1, (Juni 2015) ISSN 2460-7041

Pelaporan data dari sarana distribusi dan sarana pelayanan pada setiap proses bisnis dilakukan menggunakan SMS. SMS yang dikirimkan akan masuk ke dalam SMS Gateway dan diproses untuk mengakses perintah yang diinginkan pada database yang dituju sesuai dengan format SMS yang ditentukan. Database server terdapat pada Kementrian Kesehatan sebagai penanggung jawab atas proses distribusi obat di seluruh Indonesia. Notifikasi pada setiap pelanggaran, ditandai dengan munculnya warning dalam bentuk perubahan warna tampilan pada layar aplikasi desktop.

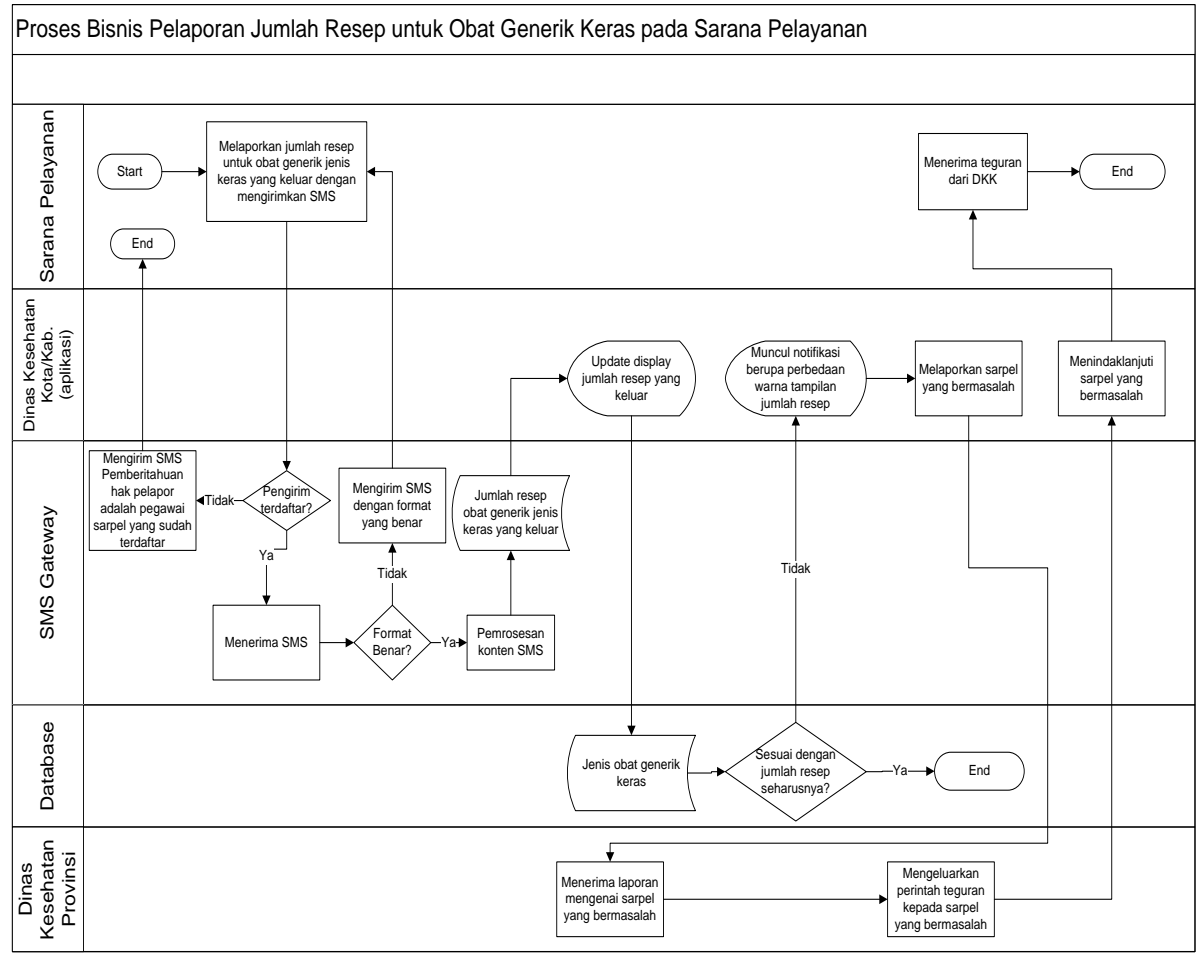

Gambar 14: Proses Bisnis Pelaporan Jumlah Resep Sarana Pelayanan

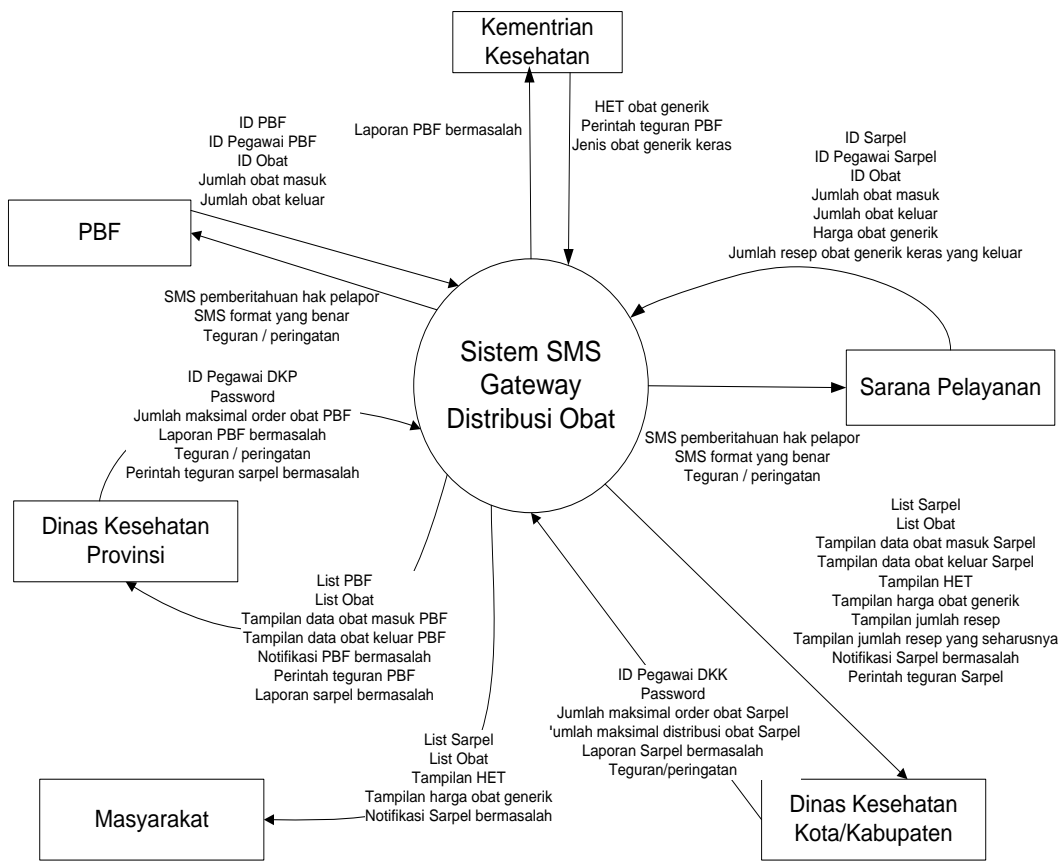

Gambar 15: DFD level 0 (diagram konteks) 


\section{DFD (Data Flow Diagram)}

DFD menggambarkan aliran data yang masuk dan keluar pada setiap stakeholder. Gambar 6 berikut menunjukkan DFD level 0 (diagram konteks) yang dirancang untuk sistem informasi monitoring distribusi obat.

DFD level 0 ini menunjukkan data apa saja yang keluar dan masuk pada setiap stakeholder. Data ini belum sempurna dan hanya menampilkan data yang secara umum harus ada serta sangat mungkin untuk ditambahkan saat pembangunan sistem yang sebenarnya.

\section{KESIMPULAN}

Sistem informasi yang akan dirancang sudah mengakomodasi berbagai kebutuhan stakeholder dalam pelaporan dan pemantauan data distribusi obat sehingga dapat dilanjutkan ke tahap perancangan sistem yang lebihrinci.

Sistem ini memliki kemampuan memberi warning atau notifikasi sehingga dapat mengurangi terjadinya kesalahan dan kecurangan yang terjadi dalam proses distribusi obat.

Pengelolaan data distribusi obat ini dapat menjadidatabase berskala nasional. Untuk keperluan lebih lanjut, databaseini dapat digunakan oleh lembaga lain yang mengurus segala hal mengenai obat seperti BPOM.

\section{REFERENSI}

[1] Whitten, J.L., \& Bentley, L. D. (2005). Systems Analysis and Design Methods $7^{\text {th }}$ Ed. New York: McGraw Hill.

[2] Saleem, M., \& Doh, K.-G. (2009). Generic Information System Using SMS Gateway. Fourth International Conference on Computer Science and Convergence Information Technology (pp.861 -866). Ansan, South Korea: Department of Computer Science and Engineering, Hanyang University.

[3] FKMUA.(2011, Oktober). Konsep Penyebab Penyakit. Retrieved Juni 9, 2013, from ikma10fkmua.wordpress.com: http://ikma10fkmua.wordpress.com/ 2011/10/25/epid-pencegahanpenyakit/

[4] (2011, Juni). Indonesia. Retrieved Juni 1, 2013, from indonesia.bg: http://www.indonesia.bg/indonesian/indonesia/index.htm

[5] (2012, Maret). Jumlah Penduduk Indonesia 2012. Retrieved Juni 1, 2013, from tutorialto.com: http://www.tutorialto.com/pendidikan/864jumlah-penduduk-indonesia-2012.html

[6] Maximillian.(2008, Maret). Strategi Marketing dan Distribusi Obat. Retrieved Juni 2, 2013, from bisnisfarmasi.wordpress.com: http://bisnisfarmasi.wordpress.com/2008/03/16/strategi-marketingobat-a-little-bit-of-writer\%E2\%80\%99s-stupid-talk

[7] Natalia, Lamtiur Kristin.(2012, Juni). Jumlah Penduduk Indonesia Bisa Tembus 330 Juta Jiwa. Retrieved Juni 1, 2013, from news.okezone.com:

http://news.okezone.com/read/2012/06/29/337/655692/jumlahpenduduk-indonesia-bisa-tembus-330-juta-jiwa

[8] R.H, Priyambodo.(2012, Mei). IAI: Distribusi Obat Terlalu Bebas. Retrieved Juli 7, 2013, from antaranews.com: http://www.antaranews.com/berita/1274177602/iai-distribusi-obatterlalu-bebas

[9] Rahman, Fathur.(2012, November). Perlunya Perbaikan Sistem Pelayanan Kesehatan di Indonesia untuk Mengurangi Terjadinya Kasus Malpraktek..Retrieved Juni 12, 2013, from kesehatan.kompasiana.com: http://kesehatan.kompasiana.com/medis/2010/11/19/perlunyaperbaikan-sistem-pelayanan-kesehatan-di-indonesia-untukmengurangi-terjadinya-kasus-malpraktek

[10]Ramadhika.(2012).SMS Gateway Menggunakan Gammudan MySQL. Retrieved Agustus 15, 2013, from ubaya.ac.id: http://www.ubaya.ac.id/2013/content/articles_detail/33/SMS-Gatewaymenggunakan-Gammu-dan-MySQL.html 